\title{
Provenance and geological significance of red mud and other clastic sediments of the Mugnano Cave (Montagnola Senese, Italy)
}

\author{
Francesco Iacoviello ${ }^{1}$ and Ivan Martini ${ }^{1}$
}

\begin{abstract}
:
lacoviello F., Martini I. 2012. Provenance and geological significance of red mud and other clastic sediments of the Mugnano Cave (Montagnola Senese, Italy). International Journal of Speleology, 41(2), 317-328. Tampa, FL (USA). ISSN $0392-6672$. http://dx.doi/org/10.5038/1827-806X.41.2.17

The Mugnano Cave is characterized by a thick clastic sedimentary fill showing a great variability of sedimentary facies, ranging from clay to coarse-grained sand deposits. This paper deals with combined sedimentological and mineralogical (XRD and SEM) studies of these sediments and bedrock insoluble residues in order to understand the origin and geological significance of cave deposits, with particular attention to red mud sediments, often considered as the residue of host rock dissolution. Three different sedimentary facies were recognized: i) YS, yellow sand with occasionally shell fragments, testifying the arrival of sediments from the surrounding landscape; ii) RS, red laminated mud; iii) GS, grey and red-grey mud and sand, dolomite-rich sediments. Furthermore, the results obtained in the present study allowed the identification of two fingerprint minerals: i) quartz, present only as traces in the limestone host-rock, and ii) dolomite, certainly related to the incomplete bedrock dissolution. Results obtained by this multidisciplinary approach testify that no one of the investigated sediments is representative of a completely autochthonous sedimentation (i.e. accumulation of insoluble residue of limestone in a cave environment). In fact, all the three sedimentary facies show a bulk composition rich in quartz, a mineral indicating an external origin for these sediments. Also the grey sediments, despite of their high content of bedrockrelated dolomite, are quite rich in quartz and they testify the mixing of autochthonous and allocthonous sediments. The clay fraction of cave sediments shows strong compositional similarities with bedrock insoluble residue and consequently its analysis cannot be considered as a clear proxy for distinguishing between different parent materials. Therefore, the origin of these cave deposits is dominantly related to external sediments inputs, with terra rossa surface soils as the most probable parent material for red mud sediments.
\end{abstract}

Keywords: cave sediments; red mud; Mugnano Cave; Montagnola Senese Received 13 December 2011; Revised 7 February 2012; Accepted 22 June 2012

\section{INTRODUCTION}

Clastic and chemical cave sediments have attracted geoscientists due to their importance as a potential source of information regarding the evolution of karst systems, paleoclimatic reconstructions and for their implications in archaeology and paleontology. Chemical deposits (e.g. speleothems) are formed in place, through precipitation from solutions, and for this reason they are autochthonous. Regarding the clastic sediments inside caves, there are two possible origins (Ford \& Williams, 2007): allochthonous, such as stream flows or infiltrations from soils, or autochthonous, deriving from the weathering of the host rock. Distinguishing between these two possible origins is quite difficult, especially for the clayey/muddy por-

${ }^{1}$ Department of Earth Sciences, University of Siena, via Laterina 8, 53100, Siena, Italy

Corresponding author: (martini.ivan@unisi.it) tion of sedimentary infill. In some cases (Lynch et al., 2003; Martín-Pérez et al., 2010; Martín-García et al., 2011) strong differences or similarities in the chemical and mineralogical composition of the clay fraction and of the insoluble residue of bedrock, are good markers for understanding the origin of cave sediments. In other cases some sedimentological features (e.g. lacking of sedimentary structures indicative of transport, no evidence of major stream transporting clastic sediments, widespread occurrence of red clays covering host rock of the cave, etc). are taken into account as indicating an in-situ origin for these sediments (Ford \& Williams, 2007; Lynch et al., 2003; Martín-Pérez et al., 2010; Martín-García et al., 2011). However, these features can only suggest a similar origin but they do not exclude other ones: for example, autochthonous clay particles coating cave walls can be washed off by dripping water, then they can be transported in hydrodynamic quiet environments (e.g. subterranean lake or swamp area) and re-deposited. In this way they form fine-laminated packages of clay, with sedi- 
mentological features analogues to clays that come from outside the cave through sediment-laden flows.

The origin of such deposits is an open question not only in cave sediments studies: indeed, red clays are frequently associated with carbonate rocks, forming red soils (also called terra rossa), that are up to several meters thick and that are widespread across karst areas especially in regions with a Mediterranean climate (Durn, 2003; Priori et al., 2008; Muhs et al., 2010 and reference therein). The origin and the geological significance of red clays have been debated for a long time and traditionally two major theories, the "residual" and the "detrital" ones, are taken into account. According to the residual origin hypothesis, red clays are the insoluble residue left by limestone dissolution (Reifenberg, 1947; Dudal et al., 1966; Moresi \& Mongelli, 1988). The main problem with this hypothesis (pointed out by nearly every proponent of the detrital theory) is that limestones generally contain little or no clay or other insoluble minerals (Ruhe et al., 1961; Ruhe, 1975; Comer, 1976; Mee et al., 2004; Schatetzl \& Anderson, 2005), so non-realistic large thicknesses of limestone would have to be dissolved to give a significant thickness of red clays. On the other hand, according to the detrital theory, red clays are formed by the accumulation of alluvial mud, volcanic ash and/or eolian dust on limestones (Yaalon and Ganor, 1973; Jackson et al., 1982; Muhs et al., 2010). However, this hypothesis does not account for the worldwide association of terra rossa with karst carbonate rocks (see Merino and Banerjee, 2008 for a global review). Besides, other authors take into account the possibility of a polygenetic nature of these soils related to the mixing of insoluble residue of carbonates with other parent materials (Yaalon, 1997; Durn et al., 1999).

Red clays are a powerful archive of information that can be used to unravel the landscape evolution of an area and, for this reason, understanding their origins is of great importance. This is particularly true for red clays in cave, where they can constitute the overall deposits or can be associated with coarser sediments.

This paper deals with a combined sedimentological and mineralogical analysis of some muddy-rich clastic cave deposits exposed in the Mugnano Cave (Siena district, Italy) in order to better understand their origins and their relationships with terra rossa soils, which are widespread in the surrounding areas.

\section{GEOLOGICAL SETTING}

The cave investigated in the present work is located in the Montagnola Senese, a series of N-S aligned hills west of Siena (Tuscany, Italy). This area is included in the inner Northern Apennines (Fig. 1a-b), a fold-thrust chain formed during the Tertiary in response to the interaction between the Adria and Corso-Sardinian microplates (Carmignani et al., 2001 and references therein). The Montagnola Senese corresponds to a morpho-structural high, bounded by tectonic depressions characterized by continental and marine siliciclastic sedimentation during late Miocene and Pliocene time (Martini et al., 2011 and reference therein). This morpho-structural high is mostly

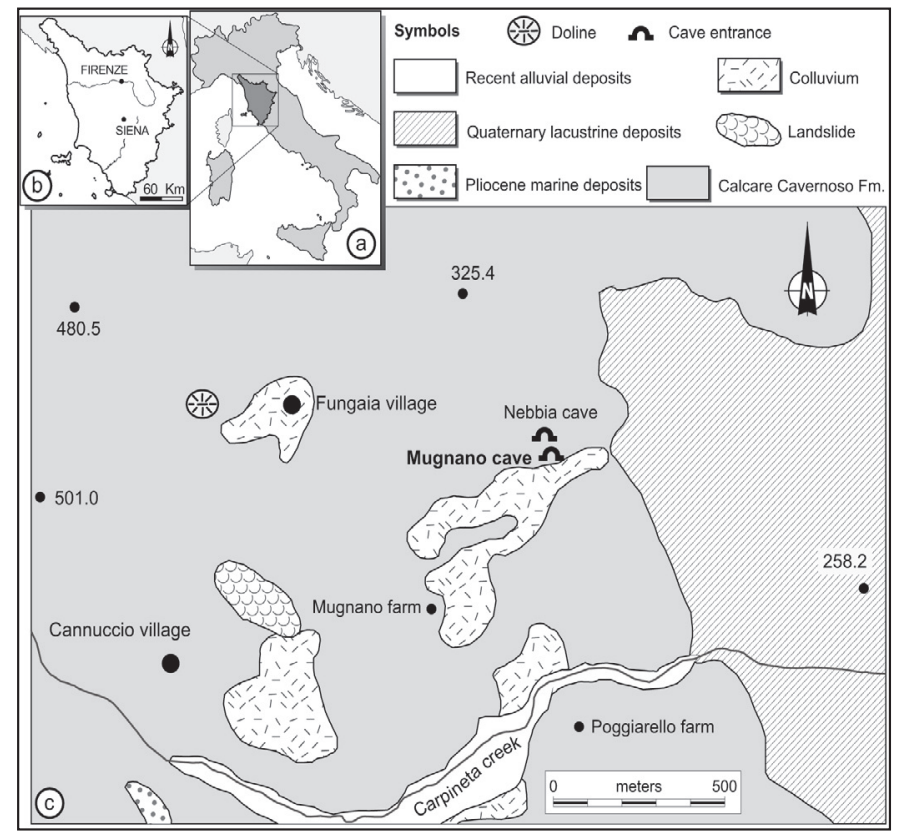

Fig. 1. (a-b) Geographical location of the Mugnano Cave; (c) Geological map of the area surrounding the cave (modified from Martini, 2011).

made of non-metamorphic karst terrain and only in the southern sector metamorphic rocks crop out extensively (Giannini \& Lazzarotto, 1970). The nonmetamorphic rocks are substantially represented by two genetically-related formations: the "Calcare Cavernoso" and the "Breccia di Grotti" Fms. In detail, the Calcare Cavernoso Fm. consists of clast- to matrixsupported dolomitic limestone with a characteristic vacuolated texture (Passeri, 1975, 1979; Gandin et al., 2000; Lugli, 2001; Lugli et al., 2002). During the last century many authors (Signorini, 1946; Merla, 1952; Trevisan, 1955) focused their attention on the Calcare Cavernoso Fm. in order to understand its origin and age, but only recently Gandin et al. (2000) demonstrated that this rock was formed during the Neogene as a consequence of the dissolution of sulphates and destabilization of the original brecciated dolostone (the Triassic Burano Anhydrite Fm).. The Calcare Cavernoso Fm. contains a peculiar lithofacies known as "Cenerone" (Passeri, 1975). It is made up of grey, powdery or sandy dolomite that forms masses or lenses characterized by a poor degree of cohesion (Gandin et al., 2000; Lugli, 2001). The origin of this incoherent lithofacies is related to weathering processes that affected the remnants of the original dolomitic clasts (Gandin et al., 2000; Lugli, 2001). The features of this lithofacies are similar to the weathering-derived residual sediment of impure limestone, observable in many other karst areas (Burger, 1989; Vergari \& Quinif, 1997; Tognini, 1999; Quinif et al., 2006).

The Breccia di Grotti Fm. is lithologically similar to the Calcare Cavernoso Fm. (Signorini, 1966; Giannini \& Lazzarotto, 1970) as it made up of continental breccias and sandstones, with a great dominance of "Calcare Cavernoso" elements, deposited during the Neogene in palaeo-morphological depressions, in an alluvial fan setting. 


\section{CAVE DESCRIPTION}

The Mugnano Cave (T/SI 258 in the Tuscan register of caves, also known as "Leccione cave") is one of the most extended cavity of the Montagnola Senese karst area (Siena district, Northern Appennines, Italy), which is characterized by the presence of about 80 small caves. The Mugnano Cave entrance has its opening at an altitude of $306 \mathrm{~m}$ in the Fungaia area (Fig. 1c), a hilly region with the highest altitude represented by Monte Maggio (671 $\mathrm{m}$ a.s.1).. This sector of the Montagnola Senese is bounded to the North and South by two plains, called respectively "Pian del Casone" and "Pian del Lago" (both about $280 \mathrm{~m}$ a.s.1).. The origin of the northern one is generally referred to a tectonic basin (Capezzuoli et al., 2009); while "Pian del Lago" appears as a large and closed depression delimited by karst terrain, that has generally been interpreted as a polje (Pascucci \& Bianciardi, 2001; Pascucci, 2004). Palustrine-lacustrine sediments occur in both these two flat areas, testifying the presence of two important Quaternary lakes, which existed until the $18^{\text {th }}$ century when they were drained for agricultural purpose (Pascucci, 2004).

The Mugnano Cave is entirely developed in the Calcare Cavernoso Fm. and the entrance consists of a $6 \mathrm{~m}$-deep shaft that leads into the first big chamber (Fig. 2). Some narrow passages connect the many rooms of the cavity. The cave is currently dry and it is characterized by the general absence of dripwater speleothems. The sedimentary infill of this cav- ity is one of its most striking features (Fig. 3) and it was recently investigated by Martini (2011). The same author, on the basis of sedimentological and stratigraphic evidences, interpreted the origin of this cave in the framework of the rock-ghost weathering theory (Quinif, 2010 and references therein). This recent theory described an important speleogenetic process that act mainly on the karstification of impure limestone (Vergari \& Quinif, 1997; Tognini, 1999; Häuselmann \& Tognini, 2005; Quinif et al., 2006; Audra et al., 2007; Quinif, 2010) and of noncarbonate rocks (in this case designed with different terms, see Piccini \& Mecchia, 2009, for a comprehensive review). According to this hypothesis, the rock was firstly affected by an "in-situ" weathering during a long-term stability of the base level, resulting in the incomplete dissolution of a portion of the rock massif. The dissolution affects the more soluble mineralogical phases of the host-rock (e.g. calcite, in impure limestone), while the less soluble ones (e.g. dolomite, quartz, clay minerals) are few or non-affected by dissolution. This condition allowed the insoluble materials to remain in place, preserving the structure of the parent rock, but with the consequent increase in rock porosity. At this point, residual and unconsolidated materials can be eroded and removed by seepage waters (piping processes), forming conduits and cavities, and facilitating the development of an underground drainage network (with a greater capacity to remove the weathered part of the bedrock).

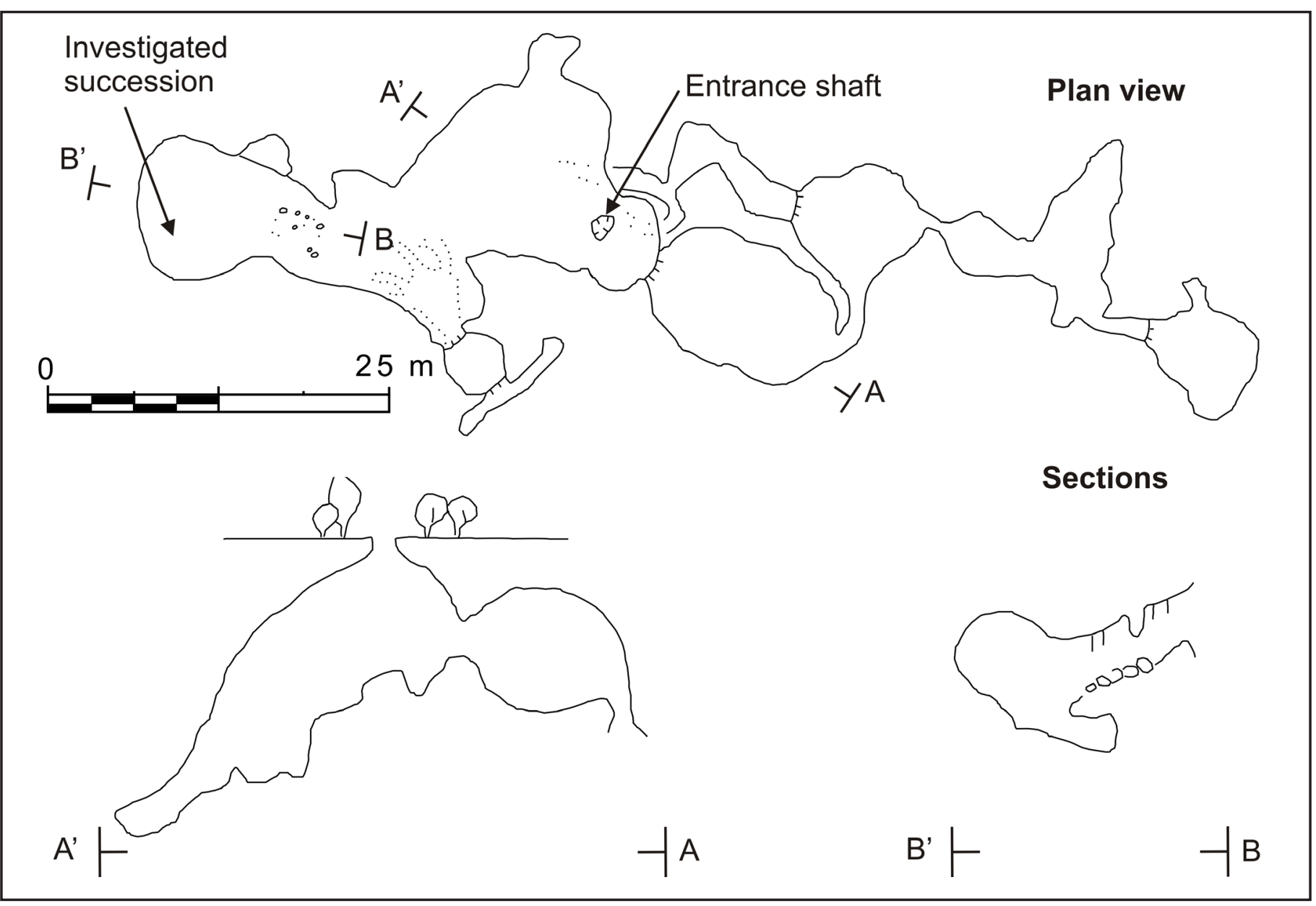

Fig. 2. Map of the Mugnano Cave and location of the investigated sedimentary succession (modified after Fabrizi, 1962). 


\section{METHODS}

The collected sediments were analyzed through a multidisciplinary approach including X-Ray Diffractometry (XRD), SEM (Scanning Electron Microscopy) and sedimentological analysis. Two insoluble residues of bedrock were analyzed with the same methodology. Insoluble residues were obtained attacking crushed fragments of limestone with a $1 \mathrm{M}$ Sodium Acetate (NaOAc) solution buffered at $\mathrm{pH} 5$ with Acetic Acid (HOAc) following the methodology proposed by Jackson (1979) and Tassier et al. (1979). The acid attack was followed by the washing of samples with deionized water in order to remove acid traces and then the samples were dried at $50^{\circ} \mathrm{C}$.

The descriptive sedimentological terminology used is from Harms et al. $(1975,1982)$ and Collinson and Thompson (1982). Sediments colour was determined by the Munsell ${ }^{\circledR}$ soil colour charts on both wet and dry samples (reported in Table 1).

SEM analysis were performed with a Philips XL30 device operated at $20 \mathrm{kV}$ and equipped with an EDAX energy-dispersive (EDS) X-ray spectrometer. The investigated sediments had been previously mounted onto a slide and then coated with graphite.

XRD analysis were performed both on the bulk and clay fraction of each sample. XRD measurements were conducted with an automated Philips PW1710 Bragg-Brentano diffractometer, using CuKa radiation (40 kV, $20 \mathrm{~mA})$. Diffractograms were processed using the "MacDiff" software (Petschick, 2001).

\section{XRD analysis of bulk samples}

The mineralogical assemblage of the bulk sediments was determined by XRD using randomly oriented powders obtained by crushing the sediments in an agate mortar. Each sample was analyzed between $2^{\circ}$ and $70^{\circ} 2 \theta$, with a step size of $0.02^{\circ} 2 \theta$, in the airdry state.

The following peaks were identified $\left({ }^{\circ} 2 \theta\right)$ : the major quartz peak at $26.67^{\circ} 2 \theta$ (3.34 $\AA$ ), the feldspar peaks at $27.52^{\circ} 2 \theta(3.24 \AA)$ and $27.95^{\circ} 2 \theta(3.19 \AA)$, the major illite peak at $\sim 8.8^{\circ} 2 \theta(10 \AA)$, the major dolomite peak at $30.98^{\circ} 2 \theta(2.89 \AA)$. The sum of kaolinite and chlorite was determined by their common peak at $12.5^{\circ}$ $2 \theta$, due to the difficulty to discriminate these phases by random oriented powder XRD. The term "illite" is used according to the definition proposed by Grim et al. (1937).

Mineralogical semiquantitative estimations of bulk samples were obtained using the methodology proposed by Biscaye (1965) for clay minerals and by Svensson et al. (2000) for the non-clay components. With this approach the quantities do not represent the physical sample composition by weight. However, as long as the results are used only for comparison between samples analyzed in the same way, this is a reasonable approximation.

Iron oxides (that are the main responsible of red colour in cave sediments) are present in all the investigated sediments. However, due to their small amount and low cristallinity they show subtle peaks in XRD analysis. For this reason they were not considered in semi-quantitative XRD analysis and their most important features were investigated by SEM and described in the text.
Table 1. Synthesis of the investigated samples with particular reference to their lithology (see the text for the explanation) and to their wet and dry Munsel|® colour.

\begin{tabular}{cccccc} 
Sample & Lithology & \multicolumn{4}{c}{ Munsel1 ${ }^{\circledR}$ color } \\
\cline { 4 - 6 } MU 23 & GS1 & 2.5 YR & $3 / 4$ & $7.5 \mathrm{YR}$ & $6 / 8$ \\
MU 22 & GS2 & $5 \mathrm{YR}$ & $4 / 3$ & $7.5 \mathrm{YR}$ & $5 / 6$ \\
MU 21 & GS2 & 10 YR & $5 / 1$ & $7.5 \mathrm{YR}$ & $5 / 1$ \\
MU 20 & GS2 & 10 YR & $4 / 1$ & $7.5 \mathrm{YR}$ & $5 / 1$ \\
MU 19 & GS2 & $7.5 \mathrm{YR}$ & $4 / 3$ & $7.5 \mathrm{YR}$ & $5 / 4$ \\
MU 18 & GS1 & $7.5 \mathrm{YR}$ & $4 / 3$ & $7.5 \mathrm{YR}$ & $6 / 8$ \\
MU 17 & GS1 & $2.5 \mathrm{YR}$ & $3 / 3$ & $7.5 \mathrm{YR}$ & $5 / 6$ \\
MU 16 & GS1 & $5 \mathrm{YR}$ & $4 / 3$ & $7.5 \mathrm{YR}$ & $4 / 4$ \\
MU 15 & GS2 & $2.5 \mathrm{YR}$ & $4 / 2$ & $7.5 \mathrm{YR}$ & $5 / 4$ \\
MU 14 & RS & $2.5 \mathrm{YR}$ & $4 / 6$ & $5 \mathrm{YR}$ & $5 / 8$ \\
MU 13 & RS & $2.5 \mathrm{YR}$ & $4 / 8$ & $5 \mathrm{YR}$ & $6 / 8$ \\
MU 12 & RS & $2.5 \mathrm{YR}$ & $4 / 6$ & $5 \mathrm{YR}$ & $6 / 8$ \\
MU 11 & YS & $5 \mathrm{YR}$ & $5 / 4$ & $5 \mathrm{YR}$ & $7 / 6$ \\
MU 10 & RS & $2.5 \mathrm{YR}$ & $4 / 6$ & $5 \mathrm{YR}$ & $6 / 8$ \\
MU 9 & RS & $2.5 \mathrm{YR}$ & $4 / 8$ & $5 \mathrm{YR}$ & $5 / 6$ \\
MU 8 & RS & $2.5 \mathrm{YR}$ & $4 / 8$ & $5 \mathrm{YR}$ & $5 / 6$ \\
MU 7 & RS & $2.5 \mathrm{YR}$ & $3 / 6$ & $5 \mathrm{YR}$ & $6 / 8$ \\
MU 6 & RS & $2.5 \mathrm{YR}$ & $3 / 6$ & $5 \mathrm{YR}$ & $6 / 6$ \\
MU 5 & RS & $2.5 \mathrm{YR}$ & $4 / 6$ & $5 \mathrm{YR}$ & $6 / 8$ \\
MU 4 & YS & $2.5 \mathrm{YR}$ & $3 / 4$ & $5 \mathrm{YR}$ & $5 / 6$ \\
MU 3 & RS & $2.5 \mathrm{YR}$ & $4 / 6$ & $5 \mathrm{YR}$ & $6 / 6$ \\
MU 2 & YS & $2.5 \mathrm{YR}$ & $3 / 4$ & $5 \mathrm{YR}$ & $6 / 8$ \\
MU 1 & YS & $2.5 \mathrm{YR}$ & $3 / 6$ & $5 \mathrm{YR}$ & $7 / 6$
\end{tabular}

\section{XRD analysis of clay fraction}

The clay mineral assemblage was determined using texturally oriented samples. The clay fraction $(<2 \mu \mathrm{m})$ was isolated in settling tubes. Clay samples were placed on glass slides and allowed to dry in order to get oriented clay minerals. XRD patterns of oriented samples were taken after the following treatments: air drying, glycol solvation, K-saturation and heating to $550^{\circ} \mathrm{C}$ for one hour. The samples were X-rayed in the range $4-40^{\circ} 2 \theta$ with a step size of $0.02^{\circ} 2 \theta$ and a measuring time of $2 \mathrm{~s} / \mathrm{step}$. Additionally, the range $27.5-30.6^{\circ} 2 \theta$ was measured with a step size of $0.01^{\circ} 2 \theta$ and a measuring time of $4 \mathrm{~s} / \mathrm{step}$ in order to better resolve the peaks of kaolinite and chlorite (Biscaye, 1965). X-ray diffraction identification criteria were based on the suggestions of Johns et al.(1954), Biscaye (1965). Once again, the term "illite" is after Grim et al. (1937). Semi-quantitative estimation of the clay minerals was based on the procedure described by Johns et al. (1954) and using multiplication factors given by Riedmüller (1978).

\section{SEDIMENTARY FACIES AND MINERALOGICAL ANALYSIS}

The Mugnano Cave is characterized by a thick sedimentary infill, sub-divided in two units separated by a disconformity, expressed by a high-relief erosional surface (Martini, 2011). This study focuses on the sediments of the younger unit (MG2 as called by Mar- 


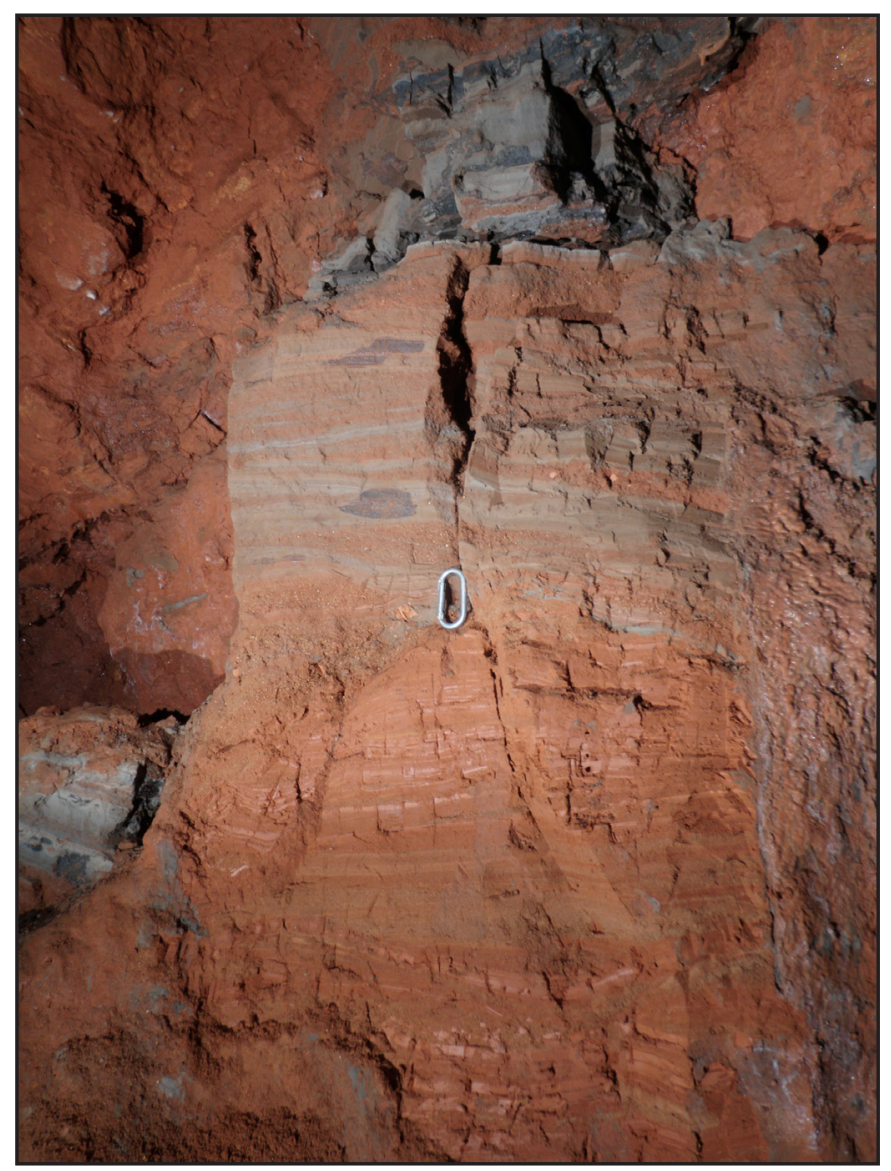

Fig. 3. The investigated sedimentary succession (the lowermost part is not visible in the figure). Carabiner for scale is about $10 \mathrm{~cm}$.

tini, 2011), that is characterized by a great variability of sedimentary facies. Sedimentological observations were carried out in correspondence of the best exposed section (Fig. 3), where a sedimentary succession more than $3 \mathrm{~m}$ thick is entirely observable. Sediment samples for laboratory investigation were collected in the same exposure (Fig. 4). Mineralogical analyses of investigated samples are synthetized in Fig. 5.

Each described deposit is coded with capital letters, with the first one indicating the dominant colour. Numbers after capital letters are locally used for a better subdivision of sedimentary facies in sub-categories.

\section{Yellow-red sand (YS)}

Sandy sediments are composed of several sedimentary facies testifying different depositional processes. A better description of these facies and of their depositional significance is given by Martini (2011). Synthetically, these sediments correspond to fine-medium grained sands (coarser sediments are present only in the upper part of the succession), organized in normally graded or ungraded beds, internally massive or showing plane- to crosslamination (Fig. 6a). Beds are tabular or inclined to adapt to the inherited morphologies and characterized by sharp base and top; gently erosional features are sometimes observable at the bottom of beds (Fig. 6a), while channelized geometries are lacking. Sandy beds are regularly interbedded with muddy sediments (RS). The sorting of sands is variable on the basis of the specific sedimentary pro- cesses that led to the deposition of each bed. Fossil shell remains (gastropods), in a poor state of preservation, were locally found inside YS sediments (Fig. 6b). According to Martini (2011) these deposits testify the arrival of turbulent sediment-laden flows in an underground lake environment. This interpretation is supported by their overall sedimentological features, the alternation between sandy and muddy facies (testifying changes in sediment supply) and the lacking of channelized facies. Similar deposits, where materials are transported into the conduit system as suspended load, are indicated in speleological literature as "slackwater deposits" (Springer \& Kite, 1997; Springer et al., 1997; Bosch \& White, 2004; White 2007).

Four samples of these sediments (MU 1-2-4-11) underwent mineralogical investigation. Their bulk mineralogical composition revealed a dominance of clay minerals and quartz, with a smaller amount

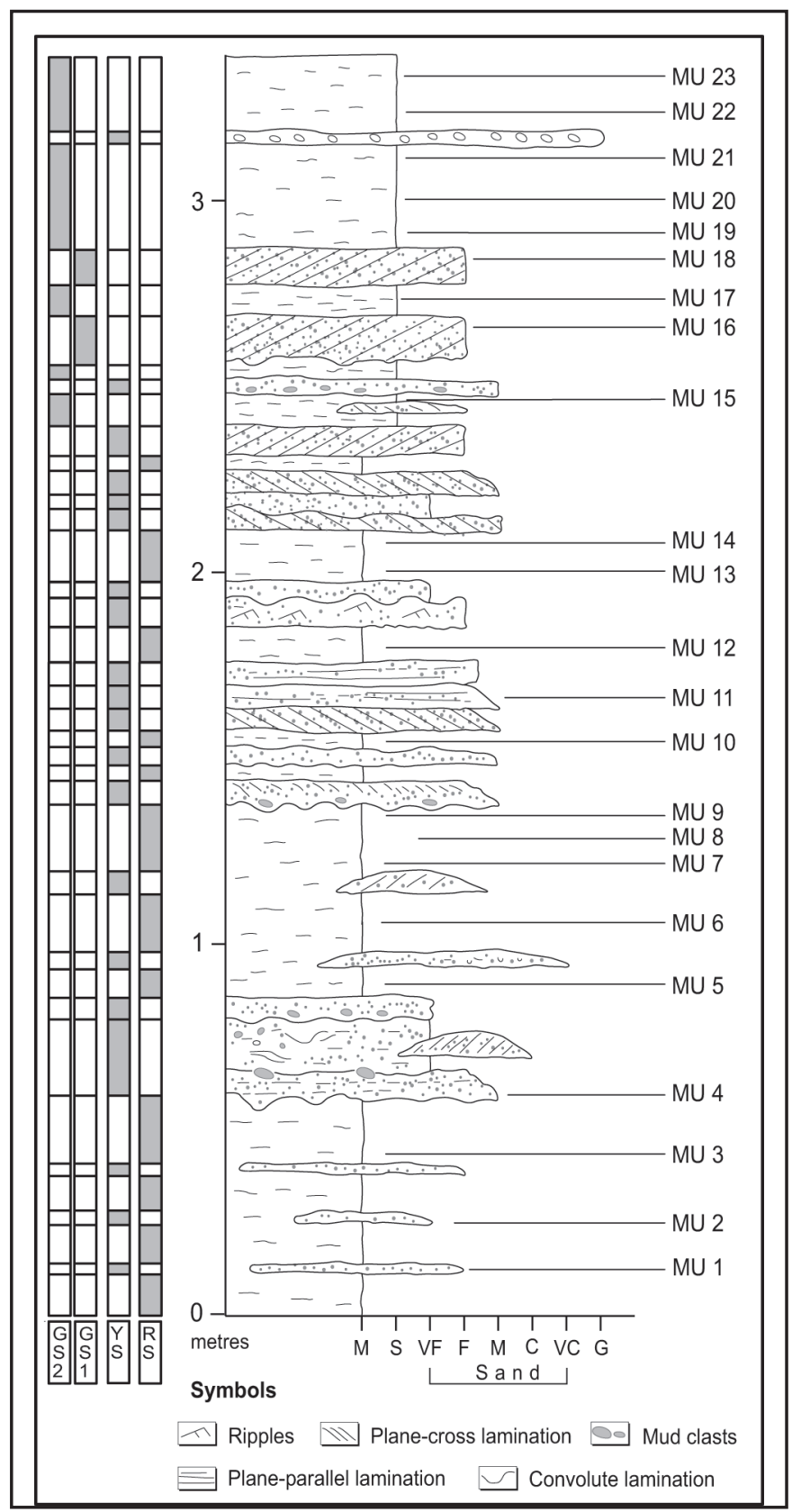

Fig. 4. Sedimentary log of the investigated succession with the localization of collected samples. 


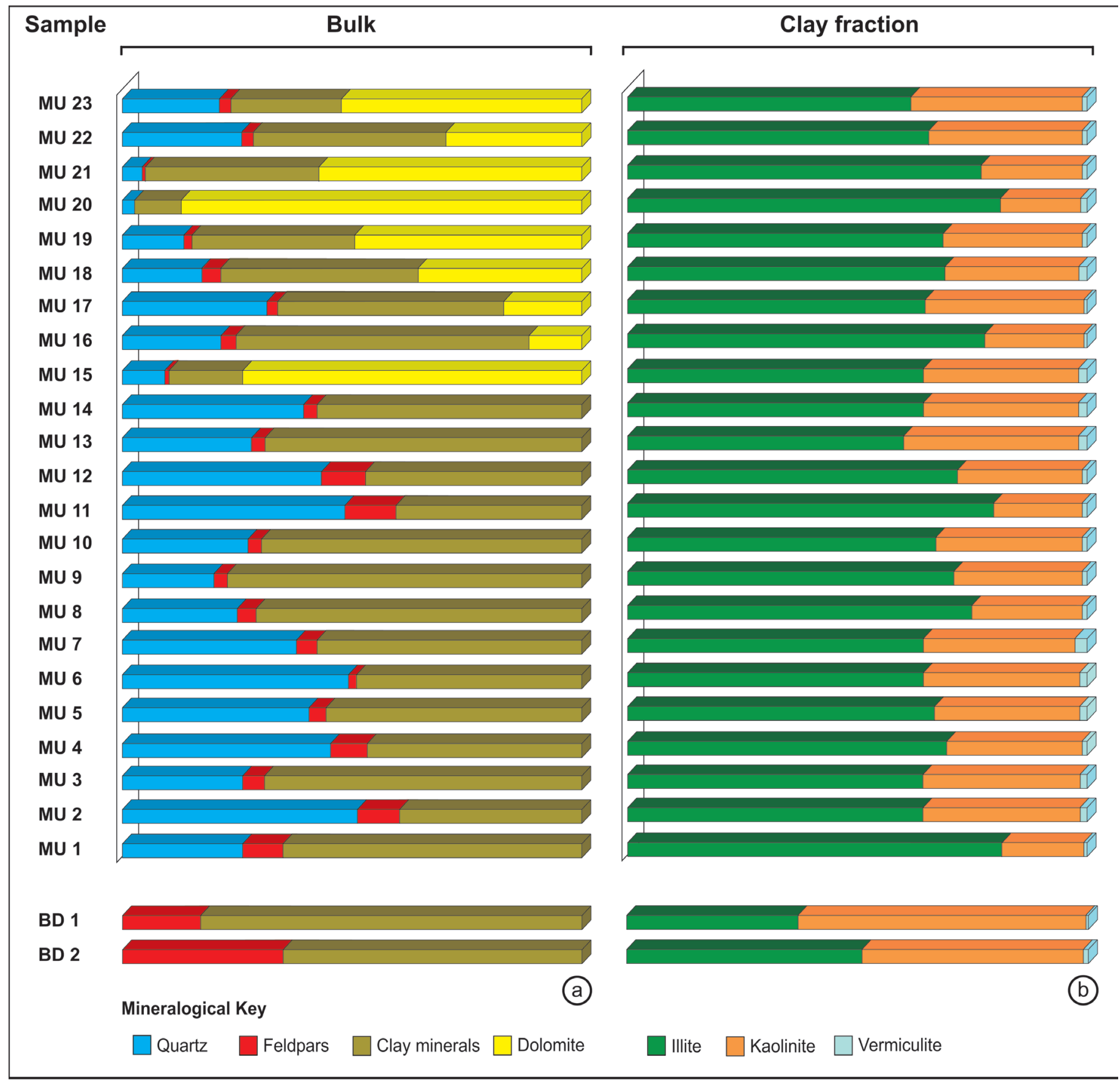

Fig. 5. (a) Bulk sample and (b) clay fraction semi-quantitative compositional analysis of the cave sediments (samples MU1-23) and of the bedrock insoluble residues (BD1-2).

of feldspars (Fig. 5a). Dolomite is absent. In detail, the clay fraction is dominated by illite and kaolinite while vermiculite is only present as traces (Fig. 5b).

SEM investigations confirm the common occurrence of quartz. Quartz grains generally show a sub-rounded shape (Fig. 6c), more rarely sub-angular, while crystal faces are very rarely preserved (Fig. 6d). Feldspars are abundant and display a well-rounded shape (Fig. 6e). Iron-oxides were occasionally found, covering detrital grains (Fig. 6f).

\section{Red mud (RS)}

The deposits of this facies are widespread in the middle-lower part of the studied section and consist of fine laminated reddish and plastic mud (Fig. 7a), where the term "mud" is indicative of a mixture of silt- and clay-size materials. Laminae are plane-parallel, generally horizontal or slightly inclined to adapt to the inherited morphologies of underlying sandy beds. Single beds range in thickness from some millimetres to some centimetres. Layers of this facies are regularly interbedded with sandy beds (facies YS), through sharp and nontransitional boundaries (Fig. 7a). Sedimentological and lithological features suggest a deposition in a subaqueous environment (e.g. underground lake) characterized by a relatively continuous supply of solid materials, where the sedimentation of red mud is the expression of periods of low sediment supply, when suspended sediments have time to settle out (Bull, 1981; Bosch \& White, 2004). 

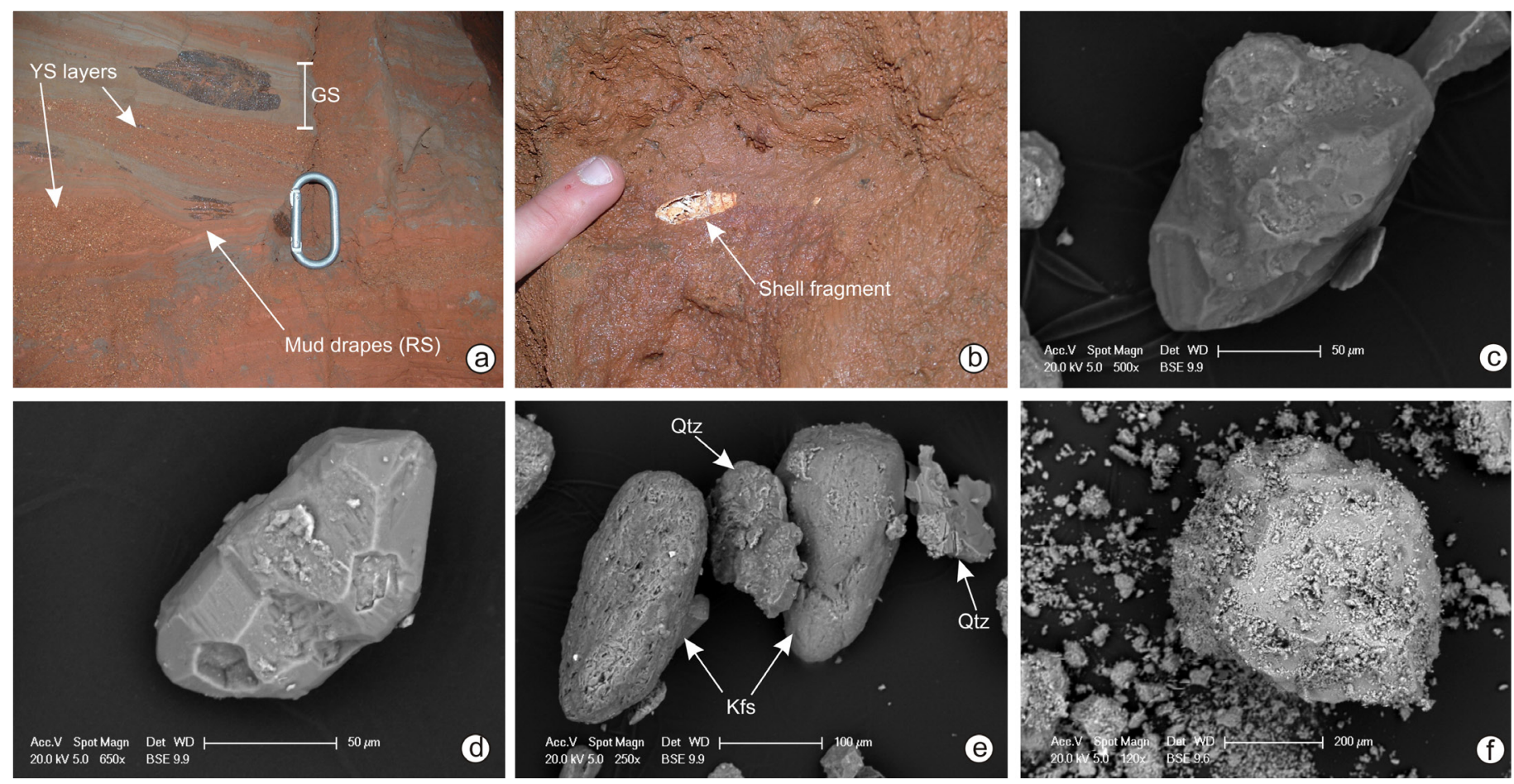

Fig. 6. (a) Typical features of YS sediments and their relations with other sedimentary facies. Carabiner for scale is about $10 \mathrm{~cm}$; (b) Shell fragment within sandy sediments. (c-f) SEM images of the main mineralogical phases constituting YS sandy deposits; (c) sub-rounded quartz grain; (d) bi-terminated quartz crystal showing a very poor degree of reworking; (e) rounded feldspar grains and angular fragments of quartz; (f) quartz grain covered by very fine-grained iron oxides and clay minerals.

Ten samples of this sedimentary facies (MU 3-56-7-8-9-10-12-13-14) underwent mineralogical investigation. XRD analysis of the bulk sediment samples (Fig. 5a) revealed a substantially homogeneous composition. Clay minerals are the dominant mineralogical phase, followed in abundance by quartz and feldspars, while dolomite is absent. Concerning the clay fraction (Fig. 5b), illite and kaolinite are the principal phases, with the first one more abundant than the second. Vermiculite is present in low percentages.

SEM observations confirmed XRD analysis and it shows that quartz grains are abundant and generally characterized by a sub-rounded shape (Fig. 7b-c). Illite (Fig. 7d) sometimes shows a corn flake feature typical of detrital origin (Ehrmann et al., 2005). Very fine iron-oxides are sometimes observed (Fig. 7b and e) and feldspars are often altered (Fig. 7f).

\section{Grey and red-grey mud and sand (GS)}

These sediments are extremely common in the upper part of the sedimentary succession and they are characterized by grey or red-grey colours (Fig. 8ab). Due to this peculiar feature these sediments are grouped in a single category, even if they consist of different lithologies. In detail, it is possible to recognize two sub-category: i) GS1, sand-dominated sediments (samples MU 16 and 18) locally containing red mud clasts (Fig. 8a-b), and; ii) GS2, muddy deposits (samples MU 15-17-19-20-21-22-23). GS1 sediments show similar lithological and sedimentological features to YS deposits, while GS2 layers are substantially constituted by non-plastic fine-grained materials, generally dominated by the granulometry of silt.
As for the processes previously described for RS sediments, the sedimentological and lithological features of sub-facies GS2 suggest a deposition in a relatively quiet and subaqueous environment as an underground lake (Bull, 1981). The origin of GS1 sandy layers are related to the arrival of sediment-laden flows in the same depositional environment (Martini, 2011).

XRD analysis on the bulk samples pointed out that dolomite is present in all samples and in some of them (MU15 and MU20) it constitutes the main mineralogical phase (Fig. 5a). Quartz and feldspars are present but generally they are less abundant than in RS and YS sediments. Clay minerals are present in all the samples with similar proportions, except for samples MU15 and MU20 that show lower clay percentages. In detail, the clay fraction shows a substantial homogeneity, with illite as the main phase and kaolinite abundant (Fig. 5b). Vermiculite is present in traces.

SEM observations confirmed the predominance of dolomite (Fig. 8c-d), quartz and feldspar, while illite is present in small aggregates (Fig. 8e). Uncommon tourmaline crystals were found in some of the analysed sample (Fig. 8f).

\section{BEDROCK RESIDUE ANALYSIS}

According to Gandin et al. (2000) the Calcare Cavernoso Fm. cropping out in this area (bedrock of the Mugnano Cave) is a dolomitic limestone with rare traces of other minerals. The acid attack on crushed limestone performed in the present study was aimed at a better investigation of the insoluble residue, constituted by non-carbonate minerals. 

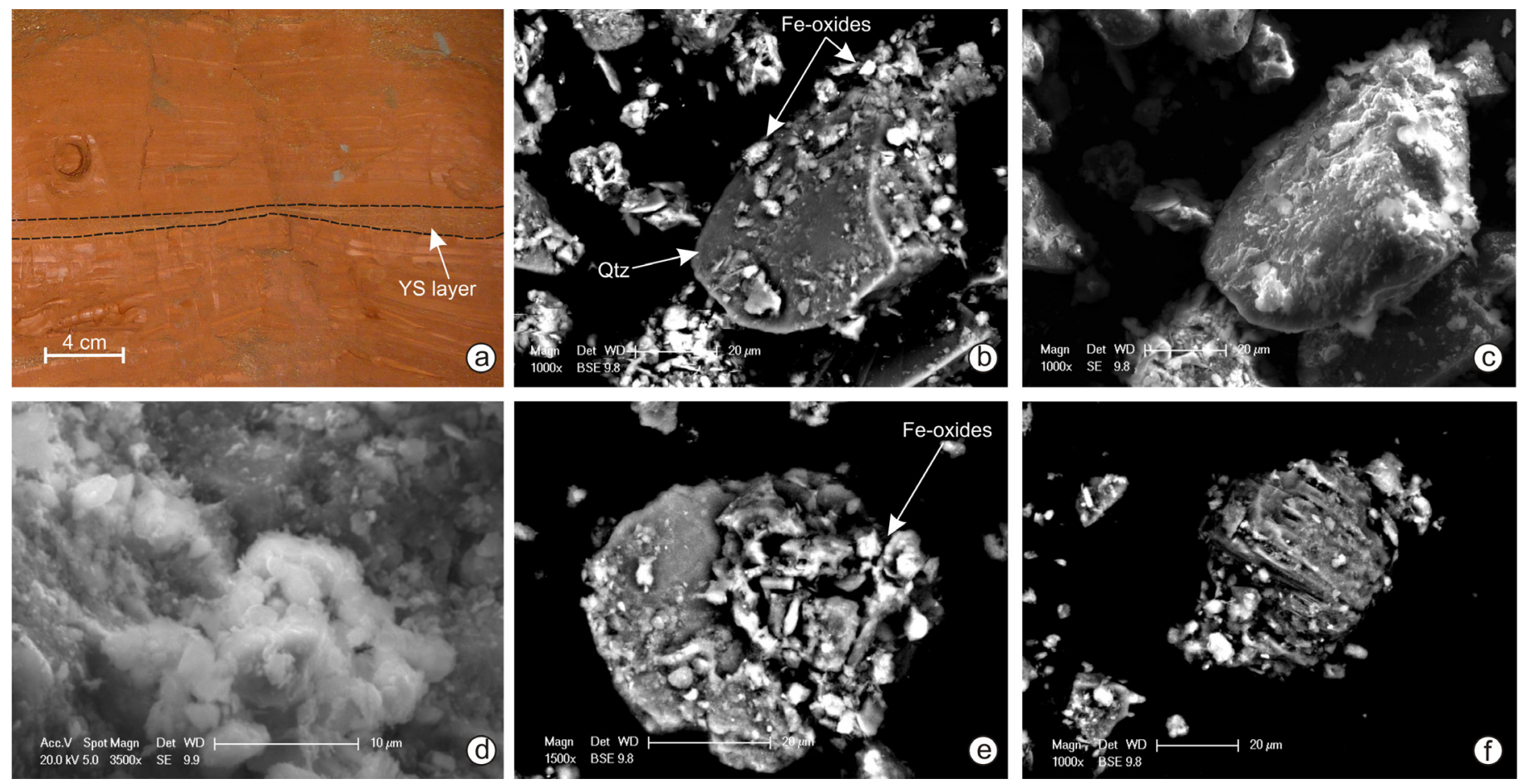

Fig. 7. (a) View of the typical appearance of RS deposits, note the interbedded sandy layer (YS) (b-f) SEM images of the main mineralogical phases constituting RS sediments; (b) quartz grain partially covered by iron oxides; (c) secondary-electrons image (SE) of the same quartz grain visible in; (b) note the sub-rounded shape; (d) corn-flake shape of detrital illite; (e) fine-grained iron oxides covering a grain; (f) feldspar grain partially altered.

XRD analysis demonstrated that insoluble residue is composed principally by clay minerals and feldspar, while quartz is not detected. Moreover, the clay fraction is mainly constituted by kaolinite and illite, with rare vermiculite.

SEM investigations confirmed XRD analysis and pointed out that quartz is extremely uncommon, since only few grains were observed (Fig. 8h). Furthermore, iron-oxides (Fig. 8g) and uncommon grains of tourmaline (Fig. 8h) were also identified.

\section{DISCUSSION}

For a better discussion concerning the origin and the geological significance of these different kinds of sediments, it is important to remark two key-points:

- The origin of dolomite fine-grained sediments has to be considered autochthonous (e.g. sediments derived within the cave and possibly moved inside the same cavity). According to Gandin et al. (2000) dolomitic materials are the residue of the incomplete dissolution of the Calcare Cavernoso Fm. (host rock of the Mugnano Cave) and form masses of poorly coherent materials. Due to their mechanical characteristics these masses can be eroded in the cave environment by flowing or dripping waters, removed from the cave system (piping processes) or re-deposited as clastic sediments (Martini, 2011);

- the deposition of facies YS is certainly related to sediment-laden flows able to transport sediments from the surrounding landscape to inside the cave, as testified by the presence of gastropod shells debris.
Red mud sediments (RS) are often considered as derived by bedrock dissolution, but in this case their mineralogical composition raises doubt about this hypothesis. In detail, RS sediments are mainly composed of quartz, clay minerals and feldspars, while dolomite is completely absent. Quartz abundance in RS sediments is in contrast with its scarcity in the insoluble residue of limestone. Furthermore, the bulk RS mineralogical composition shows strong similarities with the composition of YS sediments, which certainly derive from the outside of the cave. Moreover, the lacking of bedrock-derived dolomite can be considered as an additional clue supporting the absence of genetic relations between bedrock dissolution and RS sediments.

In contrast to RS sediments, GS ones are rich in dolomite and show traces of tourmaline, two mineralogical phases certainly present in the bedrock. However, the main part of GS analysed samples shows considerable value of quartz. The occurrence of quartz grains is difficult to explain as the consequence of an indirect enrichment of dissolved-bedrock materials. In fact, in this case the proportion between the overall mineralogical phases of host rock insoluble residues and related sediments should remain constant, while the enrichment of quartz alone is not possible. This consideration is also supported by the general low-energy hydrodynamic setting acting during the deposition (as revealed by the sedimentary structures of GS2 sediments), that realistically were unable to make a physical separation among different mineralogical phases. Consequently, the origin of GS sediments is related to the mixing of allocthonous sedi- 

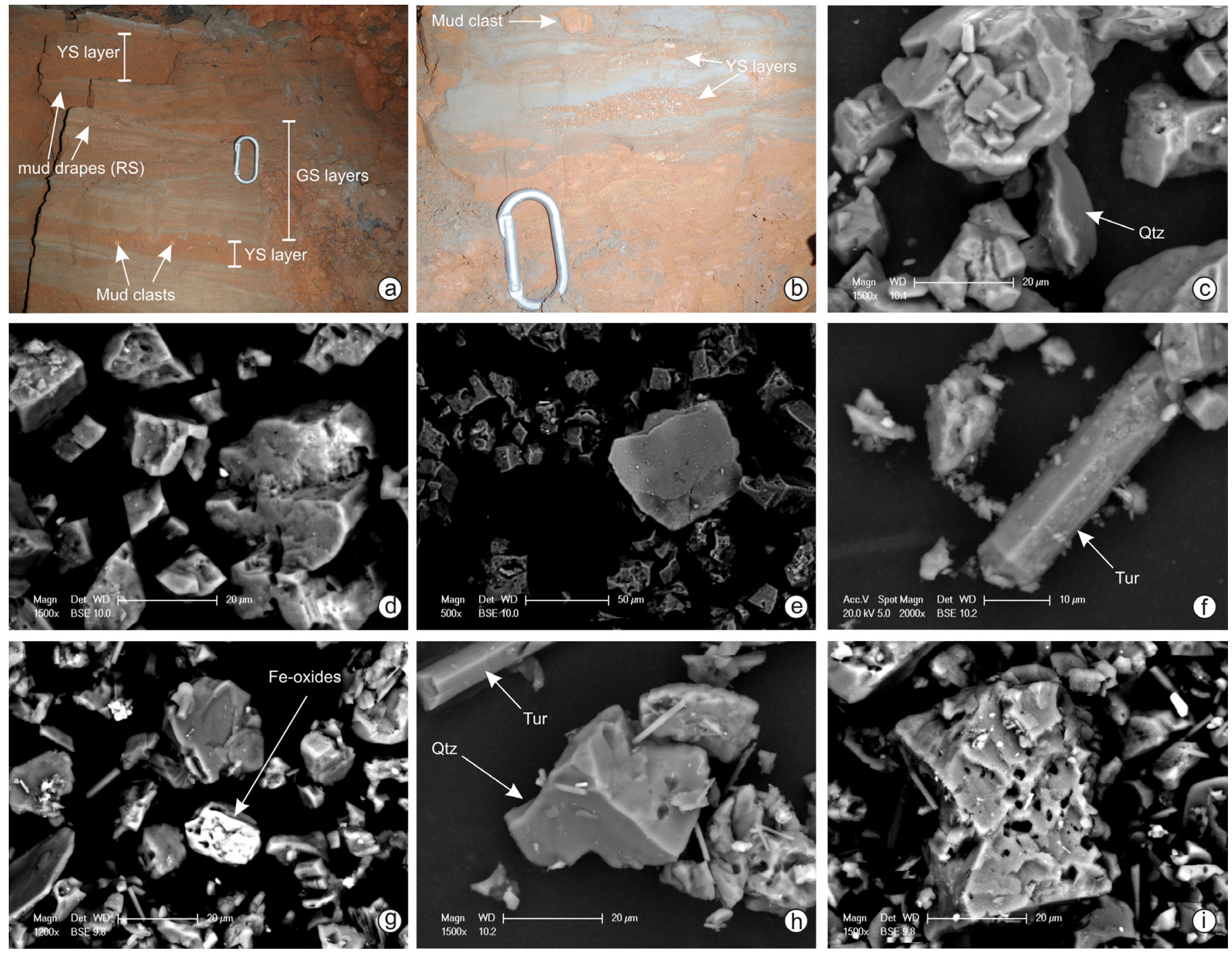

Fig. 8. (a-b) Alternation of GS beds (blue-grey in colour) with YS and RS layers. Note the mud clasts that locally occur. Carabiner for scale is about $10 \mathrm{~cm}$ (c-f) SEM images of the main mineralogical phases constituting GS deposits; (c) framework of dolomite crystals with an irregular quartz grain in the central part of the picture; (d) typical features of dolomite crystals; (e) illite aggregate on the bulk sample; (f) small tourmaline crystal (g-i) SEM images of the main mineralogical phases constituting insoluble residue of bedrock; $(\mathrm{g})$ iron oxides grain surrounded by feldspar grains; (h) angular quartz grain in the central part of the image, while a well preserved tourmaline is observable close to the top-left corner; (i) sub-angular feldspar grain.

ments (quartz-rich) and autochthonous materials (dolomite-rich). The second ones are present in the cave as a host-rock lithofacies (the "Cenerone", see the geological setting). Their erosion is probably related to turbulent flows that were able to transport sediments from the surrounding landscape inside the cave and, at the same time, to erode autochthons materials and mix them with the allocthonous ones.

\section{Clay fraction mineralogy}

The investigated sediments show a substantial homogeneity regarding the mineralogical composition and the relative abundance of each phase of the clay fraction. Three clay minerals are identified: illite is the most abundant (60-80\%), followed in abundance by kaolinite (20-40\%) and vermiculite (0.5-2\%). The same phases also constitute the clay fraction of the insoluble residue of limestone. However, in these samples kaolinite is the most common mineral (50$65 \%$ ), illite ranges between $35-50 \%$ and vermiculite is less than $1 \%$. It is possible to observe that in this case study, the clay mineral assemblages are not a distinctive feature that allows a distinction between autochthonous and allocthonous sediments, due to the occurrence of the same phases. However, the different proportions in the illite/kaolinte ratio between sediments and bedrock residues could suggest the lack of genetic relation between host rock and cave sediments.

\section{Provenance of red mud sediments}

As previously observed, the overall mineralogical compositions of red mud sediments are indicative of their allocthonous origin. The surrounding area is rich of red soils that can constitute the possible parent material for RS sediments. These soils have been extensively investigated by Costantini \& Damiani (2004), Priori et al. (2008) and Costantini et al. (2009). The same authors proposed a polycyclic and polygenetic origin for these soils, as a consequence 
of limestone dissolution and residue accumulation, in addition to an enrichments in aeolian deposits. Regardless of their origin, these authors reported mineralogical compositions that are substantially in agreement (both for the bulk and the clay fraction) with the cave sediments investigated in the present study. Consequently, surfaces soils are the most probable source of materials for these deposits.

\section{CONCLUSION}

A sedimentological and mineralogical study of some clastic deposits of the Mugnano Cave was performed in order to allow a better understanding of the origin and the geological significance of these sediments. Similar investigations were carried out also on two bedrock insoluble residue samples. On the basis of sedimentological and mineralogical features three sedimentary facies have been recognized: i) YS, yellow/red sand; ii) RS, red mud; and iii) GS, grey and red-grey mud and sand. Only YS sediments show features indicating a certain origin from outside the cave.

XRD and SEM investigations performed on red mud (RS) revealed a completely allocthonous origin also for these sediments. The comparison between the bulk mineralogical composition of RS sediments and the bulk of bedrock insoluble residue proves that the former ones did not accumulate as insoluble residue of limestone dissolution. A similar origin is possible for GS deposits: despite of the presence of a great amount of dolomite (certainly connected with incomplete bedrock dissolution), it is possible to recognize an anomalous enrichment of quartz, a phase present in the host rock only as traces. This composition is explainable only assuming a mix of autochthonous (mainly constitute of dolomite) and allocthonous (quartz-rich) sediments.

Moreover, the clay-mineral fraction of allocthonous sediments and insoluble residue of bedrock show a general homogeneity, even if they show different phases proportion. Consequently, their analysis may not be totally useful to discriminate between autochthonous versus allocthonous origin for cave sediments.

Finally, the analysis of the bulk mineralogical composition of both cave sediments and insoluble residue of bedrock allowed to identify fingerprint minerals helpful to discriminate the origin and the possible provenance of cave clastic sediments.

\section{ACKNOWLEDGMENTS}

We are grateful to Dr. Giovanna Giorgetti for constructive comments on the manuscript, Dr. Pietro Bartolini, Dr. Michele Catalucci, Dr. Simone Arragoni and all the members of Commissione Speleologica "I Cavernicoli" (C.A.I. Siena), for their assistance during fieldwork activity. We are grateful to Dr.ssa Agnese Frullatori for her help in language review. Thanks to the Federazione Speleologica Toscana (F.S.T). for the permission to publish the map of Mugnano Cave.

Prof. Ildefonso Armenteros and two others anonymous reviewers are thanked for their constructive comments on the manuscript and helpful suggestions that improved the final paper.

\section{REFERENCES}

Audra P., Bini A., Gabrovšek F., Häuselmann P., Hobléa F., Jeannin P.Y., Kunaver J., Monbaron M., Šušteršič, F., Tognini P., Trimmel H. \& Wildberger A., 2007 - Cave and karst evolution in the Alps and their relation to paleoclimate and paleotopography. Acta Carsologica, 36: 53-68.

Biscaye P.E., 1965 - Mineralogy and sedimentation of recent deep-sea clay in the Atlantic Ocean and adjacent seas and oceans. Geological Society of America Bulletin, 76: 803-832.

http://dx.doi.org/10.1130/0016-7606(1965) 76[803:MASORD]2.0.CO;2

Bosch R.F. \& White W.B., 2004 - Lithofacies and transport of clastic sediments in karstic aquifers. In: Sasowsky I.D. \& Mylroie J.E. (Eds). - Studies of cave sediments. New York: Kluwer Academic/ Plenum Publisher: 1-22. http://dx.doi.org/10.1007/978-1-4020-5766-3_1

Bull P.A., 1981 - Some fine-grained sedimentation phenomena in caves. Earth Surface Processes and Landforms, 6: 11-22. http://dx.doi.org/10.1002/esp.3290060103

Burger D., 1989 - Dolomite weathering and micromorphology of paleosoils in the Franconian Jura. Catena Supplement, 15: 261-267.

Capezzuoli E., Priori S., Costantini E.A.C. \& Sandrelli F., 2009 - Stratigraphic and paleopedological aspects from the Middle Pleistocene continental deposits of the southern Valdelsa Basin. Bollettino della Società Geologica Italiana, 128: 395-402.

Carmignani L., Decandia F.A., Disperati L., Fantozzi P.L., Kligfield R., Lazzarotto A., Liotta D. \& Meccheri M., 2001 - Inner Northern Appennines. In: Vai G.B. \& Martini I.P. (Eds). - Anatomy of an Orogen: the Appennines and adjacent Mediterranean basins. Kluwer Academic/Plenum Publisher: 197-214.

Collinson J.D. \& Thompson D.B., 1982 - Sedimentary structures. Allen \& Unwin, London, U.K., 194 p.

Comer J.B., 1976 - Genesis of Jamaican bauxite; a reply. Economic Geology, 71: 822-823. http://dx.doi.org/10.2113/gsecongeo.71.4.822

Costantini E.A.C., \& Damiani D., 2004 - Clay minerals and the development of Quaternary soils in central Italy. Revista Mexicana de Ciencias Geológicas, 21: 144-159.

Costantini E.A.C., Priori S., Urban B., Hilgers A., Sauer D., Protano G., Trombino L., Hulle D. \& Nannoni F., 2009 - Multidisciplinary characterization of the middle Holocene eolian deposits of the Elsa River basin (central Italy). Quaternary International, 209: 107-130. http://dx.doi.org/10.1016/j.quaint.2009.02.025

Dudal R., Tavernier R. \& Osmond D., 1966 - Soil Map of Europe (1:2,500,000), with explanatory text (120 p).. Food and Agricolture Organization of the United Nations, Rome.

Durn G., Ottner F, Slovenec D., 1999 - Mineralogical and geochemical indicators of the polygenetic nature of terra rossa in Istria, Croatia. Geoderma, 91: 125-150. http://dx.doi.org/10.1016/S0016-7061(98)00130-X 
Durn G., 2003 - Terra rossa in the Mediterranean region: parent materials, composition and origin. Geologica Croatica, 56: 83-100.

Ehrmann W., Setti M. \& Marinoni L., 2005 - Clay minerals in Cenozoic sediments off Cape Roberts (McMurdo Sound, Antarctica) reveal palaeoclimatic history. Palaeogeography, Palaeoclimatology, Palaeoecology, 229 (3): 187-211. http://dx.doi.org/10.1016/j.palaeo.2005.06.022

Fabrizi F., 1962 - Map of the Mugnano Cave (T/SI 258). Tuscan register of caves, Federazione Speleologica Toscana (F.S.T). http://www.speleotoscana.it/

Ford D.C. \& Williams P.W., 2007 - Karst Hydrology and Geomorphology. Wiley, $576 \mathrm{p}$.

Gandin A., Giamello M., Guasparri G., Mugnaini S. \& Sabatini G., 2000 - The calcare cavernoso of the Montagnola Senese (Siena, Italy): mineralogical-petrographic and petrogenetic features. Mineralogica et petrographica Acta, 43: 271-289.

Giannini E. \& Lazzarotto A., 1970 - Studio geologico della Montagnola Senese. Memorie della Società Geologica Italiana, 9: 451-495.

Grim R. E., Bray R. H., \& Bradley W.F., 1937 - The mica in argillaceous sediments. American Mineralogist, 22: 813-829.

Harms J.C., Southard J.B., Spearing D.R. \& Walker R.G., 1975 - Depositional environments as interpreted from Primary Sedimentary Structures and Stratification Sequences. SEPM Short Course No. 2, Lecture Note. Society of Economic Paleontologists and Mineralogists: Tulsa, OK, 153 p.

Harms J.C., Southard J.B. \& Walker R.G., 1982 - Structures and Sequences in Clastic Rocks. SEPM Short Course No. 9, Lecture Note. Society of Economic Paleontologists and Mineralogists: Tulsa, OK, 249 p.

Häuselmann P. \& Tognini P., 2005 - Kaltbach cave (Siebenhengste, Switzerland): phantom of the sandstone? Acta Carsologica, 34: 383-396.

Jackson M.L., 1979 - Soil chemical analysis advanced course. Soil Science Department, University of Wisconsin, Madison, 250 pp.

Jackson M.L., Clayton R.N., Violante E. \& Violante P., 1982 - Eolian influence on Terra Rossa soils of Italy traced by quartz oxygen isotope ratio. In: van Olphen H., Veniale F., (Eds). - Proceedings of the Seventh International Clay Conference. Amsterdam: Elsevier: 293-301.

Johns W.D., Grim R.E. \& Bradley W.F., 1954 - Quantitative estimations of clay minerals by diffraction methods. Journal of Sedimentary Petrology, 24: 242-251.

Lynch F.L., Mahler B.J. \& Hauwert N., 2003 - Provenance of suspended sediment discharged from a karst aquifer determined by clay mineralogy. In: Sasowsky I.D. \& Mylroie J.E., (Eds). - Studies of Cave Sediments. New York: Kluwer Academic: 83-94.

Lugli S., 2001 - Timing of post-depositional events in the Burano Formation of the Secchia Valley (Upper Triassic, northern Apennines) clues from gypsumanhydrite transition and carbonate metasomatism. Sedimentary Geology, 140: 107-122. http://dx.doi.org/10.1016/S0037-0738(00)00174-3
Lugli S., Morteani G. \& Dominique B., 2002 - Petrographic, REE, fluid inclusion and stable isotope study of magnesite from the Upper Triassic Burano Evaporites (Secchia Valley, northern Apennines): contributions from sedimentary, hydrothermal and metasomatic sources. Mineralium Deposita, 37: 480-494. http://dx.doi.org/10.1007/s00126-001-0251-6

Martini I., 2011 - Cave clastic sediments and implications for speleogenesis: new insights from the Mugnano Cave (Montagnola Senese, Northern Apennines, Italy). Geomorphology, 134: 452-460. http://dx.doi.org/10.1016/j.geomorph.2011.07.024

Martini I., Aldinucci M., Foresi L.M., Mazzei R. \& Sandrelli F., 2011 - Geological map of the Pliocene succession of the Northern Siena Basin (Tuscany, Italy). Journal of Maps, 2011: 193-205. http://dx.doi.org/10.4113/jom.2011.1176

Martín-Pérez A., Martín-García R., Alonso-Zarza A.M. \& Herrero M.J., 2010 - Features and origin of red clays in Castañar Cave: A touch of colour. In: Andreo B., Carrasco F., Durán J.J. \& LaMoreaux J.W. (Eds). - Advances in Research in Karst Media, Berlin: Springer: 515-520.

Martín-García R., Martín-Pérez A. \& Alonso-Zarza A.M., 2011 - Weathering of host rock and corrosion over speleothems in Castañar cave, Spain: An example of a complex meteoric environment. Carbonates and Evaporites, 26: 83-94. http://dx.doi.org/10.1007/s13146-010-0039-9

Mee A.C., Bestland E.A. \& Spooner N.A., 2004 - Age and origin of terra rossa soils in the Coonawarra area of South Australia. Geomorphology, 58: 1-25. http://dx.doi.org/10.1016/S0169-555X(03)00183-1

Merla G., 1952 - Geologia dell'Appennino settentrionale. Bollettino Società Geologica Italiana, 70: 95382.

Merino E. \& Banerjee A., 2008 - Terra rossa genesis, implications for karst, and eolian dust: A geodynamic thread. Journal of Geology, 116: 62-75. http://dx.doi.org/10.1086/524675

Moresi M. \& Mongelli G., 1988 - The relation between the terra rossa and the carbonate-free residue of the underlying limestones and dolostones in Apulia, Italy. Clay Minerals, 23: 439-446. http://dx.doi.org/10.1180/claymin.1988.023.4.10

Muhs D.R., Budahn J., Avila A., Skipp G., Freeman J. \& Patterson D., 2010 - The role of African dust in the formation of Quaternary soils on Mallorca, Spain and implications for the genesis of Red Mediterranean soils. Quaternary Science Reviews, 29: 2518-2543.

http://dx.doi.org/10.1016/j.quascirev.2010.04.013

Pascucci V. \& Bianciardi G., 2001 - Geologia e morfologia: una serie di modesti rilievi caratterizzati da una struttura complessa e da un notevole sviluppo di fenomeni carsici. In: Manganelli G. \& Favilli L. (Eds). La Montagnola Senese, una guida naturalistica - WWF Italia: 11-23.

Pascucci V., 2004 - Karst and palaeonvironment of the Siena area (Central Italy). In: Guerrieri L., Rischia I., Serva L. (Series Eds)., 32nd International Geological Conference, Florence, Italy: 20-28. 
Passeri L., 1975 - L'ambiente deposizionale della formazione evaporitica nel quadro della paleogeografia del Norico Tosco-Umbro-Marchigiano. Bollettino della Società Geologica Italiana, 94: 231-268.

Passeri L., 1979 - The hypothesis of a northern Apenninic Peninsula during the upper Triassic. Memorie della Società Geologica Italiana, 20: 151-161.

Petschick R., 2001 - MacDiff 4.2.5. http://servermac.geologie.uni-frankfurt.de/ Rainer.html

Piccini L. \& Mecchia M., 2009 - Solution weathering rate and origin of karst landforms and caves in the quartzite of Auyan-tepui (Gran Sabana, Venezuela). Geomorphology, 106: 15-25. http://dx.doi.org/10.1016/j.geomorph.2008.09.019

Priori S., Costantini E.A.C., Capezzuoli E., Protano G., Hilgers A., Sauer D. \& Sandrelli F., 2008 Pedostratigraphy of Terra Rossa and Quaternary geological evolution of a lacustrine limestone plateau in central Italy. Journal of Plant Nutrition and Soil Sciences, 171: 509-523. http:/ /dx.doi.org/10.1002/jpln.200700012

Quinif Y., Meon H. \& Yans J., 2006 - Nature and dating of karstic filling in the Hainaut Province (Belgium). Karstic, geodynamic and paleogeographic implications. Geodinamica Acta, 19: 73-85. http://dx.doi.org/10.3166/ga.19.73-85

Quinif Y., 2010 - Fantômes de roche et fantômisation. Karstologia Mémories, 18: 196 p.

Riedmüller G., 1978 - Neoformations and transformations of clay minerals in tectonic shear zones. Tschermaks Mineralogische und Petrograpische Mitteilungen, 25: 219-242. http:/ /dx.doi.org/10.1007/BF01081421

Reifenberg A., 1947 - The soil of Palestine, second ed. Thomas Murby \& Co., London, 179 p.

Ruhe R.V., Cady J.G. \& Gomez R.S., 1961 - Paleosols of Bermuda. Geological Society of America Bulletin, 72: 1121-1142. http://dx.doi.org/10.1130/00167606(1961)72[1121:POB]2.0.CO;2

Ruhe R.V., 1975 - Geomorphology. Boston, HoughtonMifflin: $246 \mathrm{p}$.

Signorini R., 1946 - Cenni preliminari su un rilevamento nella Val di Merse. Bollettino della Società Geologica Italiana, 65: 29-31.
Schaetzl R.J. \& Anderson S., 2005 - Soils: Genesis and Geomorphology. Cambridge University Press, Cambridge, $817 \mathrm{p}$.

Signorini R., 1966 - I terreni neogenici del Foglio "Siena". Bollettino della Società Geologica Italiana, 85: 639-654.

Springer G.S. \& Kite J.S., 1997 - River-derived slackwater sediments in caves along Cheat River, West Virginia. Geomorphology, 18: 91-100. http://dx.doi.org/10.1016/S0169-555X(96)00022-0

Springer G.S., Kite J.S. \& Schmidt V.A., 1997 - Cave sedimentation, genesis, and erosional history in the Cheat River Canyon, West Virginia. Geological Society of America Bulletin, 109: 524-532.

http://dx.doi.org/10.1130/0016-7606( 1997) $109<0524:$ CSGAEH $>2.3$. CO;2

Svensson A., Biscaye P.E. \& Grousset F.E., 2000 Characterization of late glacial continental dust in the Greenland Ice Core Project ice core. Journal of Geophysical Research, 105: 4637-4656. http:/ /dx.doi.org/10.1029/1999JD901093

Tassier A., Campbell P.C.G., Bisson M., 1979 - Sequential extraction procedure for the speciation of particulate trace metals. Analytical Chemistry, 5: 844-851. http://dx.doi.org/10.1021/ac50043a017

Tognini P., 1999 - The Mt. Bisbino (Northern Italy) karst: a new speleogenetic processes. Etudes de Géographie Physique, 28: 185-190.

Trevisan L., 1955 - Il Trias della Toscana e il problema del Verrucano triassico. Memorie della Società Toscana Scienze Naturali, 62: 1-30.

Vergari A. \& Quinif Y., 1997 - Les paléokarsts du Hainaut (Belgique). Geodinamica Acta, 10: 175-187.

White W.B., 2007 - Cave sediments and paleoclimate. Journal of Cave and Karst Studies, 69: 76-93.

Yaalon D.H. \& Ganor E., 1973 - The influence of dust on soils during the Quaternary. Soil Science, 116: 146-155. http://dx.doi.org/10.1097/00010694-197309000-00003

Yaalon D.H., 1997 - Soils in the Mediterranean region: what makes them different? Catena, 28: 157-169. http://dx.doi.org/10.1016/S0341-8162(96)00035-5 